\title{
PSYCHOLOGICAL CONDITIONALITY OF PROFESSIONAL REFLECTION AND BEHAVIORAL STRATEGIES IN SITUATIONS OF PROBLEMATIC INTERACTION
}

\author{
Avanesyan H. M., Karapetyan N. I., Muradyan M. D. (Yerevan State University, \\ Yerevan, Armenia) \\ avanesyanh@ysu.am,nare_karapetyan@ysu.am,maria.muradyan@ysu.am

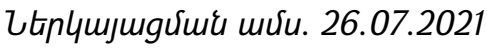 \\ ૧pupunuर्umध uर्u. 03.09.2021

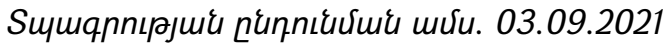

The article analyzes the problem of interpersonal interaction in the process of joint activity, which has been and remains one of the most important problems in social, organizational and management psychology. Based on the classifications of the partners in the joint activity ("unwanted", "complex", "viral", etc.) were identified characteristics and evaluation criteria for the indicated types and behavioral strategies. The aim of the study was supposed to develop, based on the characteristics of the manifesttation of the process of professional reflection in conditions of problematic interaction, a two-sided universal model for correcting self-awareness, evaluating and choosing a strategy for behavior in such situations. Comparison of psychological criteria for assessing personal manifestations and behavioral strategies in the face of overcoming problematic interactions has allowed the development and testing of training that helps to build the skill of self-regulation, evaluation, and identification of "problematic" partners, with a further search for an individual behavior strategy.

Keywords: professional reflection, behavior, projective reaction, personality, interaction, employee, coping strategy, training.

DOI: https://doi.org/10.46991/SBMP/2021.4.2.056

Relevance. In the process of many types of professional activity related to the "human-human" system, specialists often encounter various undesirable behavioral manifestations and role stereotypes of leaders, colleagues, students, clients, etc. The problems of interpersonal interaction and overcoming conflict situations in the process of joint activity remains one of the central issues in social psychology, management psychology, pedagogical and organizational psychology [12], [15].

The tendency of conflict tension during the group activity is often associated with modern transformations of society, with constant social and organizational reforms, with economic instability and informational "polyphony". Besides, a whole 
range of reasons is distinguished, such as the degree of conflict of personality, age features, status-role positions, subordination disorders, low-stress resistance or lack of self-control skills. We would like to note, that today there is a modern psychological problem of interpersonal interaction, including professional, which has acquired new, "trending" forms and it's implemented in the digital spaces, especially on the Internet and social networks. This form of "indirect" virtual interaction is manifested in forums, blogging programs, comments on personal posts that have been exposed, the targeted distribution of news or rumors, fake interpretations, etc.

Naturally, this sphere of influence directly affects the features of real professional communication, making certain adjustments to the attributes of social perception and the relationship between people. Accordingly, both in real and in the digital space a person with stressful, conflicting, uncomfortable, tense, and in ordinary situations, various destructive personality traits may appear [6].

Obviously, in these situations, a special role is assigned to the mechanisms of social perception, which cause certain factors: age, gender, habit in a broad and narrow sense [8], status, education, specialty, cultural aspects, etc. In some cases, we can say that these are models of behavior in which coping behavior or coping strategies do not work or exceed individual resources. In some situations, we can base it on the approach of D. Leontiev, who singled out the form of adaptive behavior and considered it from the perspective of a subjective assessment of the situation [14, 65-78]. But practice shows that with a certain combination of subjective factors and a real situation, arises negative behavioral reactions and manifestations of personal qualities, which complicate interpersonal relations and affect the psychological atmosphere of the entire organization, and ultimately, the effectiveness of its activities.

Apparently, this can be associated not only with the situation, but also with a certain, defensive form of coping behavior strategy, which is associated with the level of self-esteem, self-control, character accentuations, phobias and other reasons of a psychological nature [7].

In the analyzed studies on various aspects of a constructive approach when interacting with problem subjects, the role of conscious self-regulation in such situations is noted. V. I. Morosanova, considering individuality as a subject of different types of activity, characterizes mental self-regulation, which is a functional "... a subject's means and a psychological mechanism that allows him to mobilize his personal and cognitive resources for the implementation of his activity, for the promotion and achievement of its goals" [16]. In the context of the problem, it is necessary to consider some strategies for overcoming problem situations, which in the psychological literature are called the term "coping". It is well known that coping behavior is one of the main conditions for resolving a conflict situation. In 
psychology, there are a number of general approaches to the classification of coping strategies, the basic theoretical principles of which were developed at the end of the last century [2].

For example, E. I. Rasskazova and T.O. Gordeeva, based on the Ch. Carver's coping classification, argue that the most adaptive coping strategies include strategies aimed directly at resolving a problem situation [17]. In another case, coping behavior has an integrative interpretation, consisting of affective, cognitive, intentional and social factors that are manifested in coping strategies and give a person the opportunity not only to cope with stressful challenges, but also contribute to progress towards important goals for the individual. Based on this, L. Aspinwall, E. Greenglass, R. Schwarzer, S. Taubert distinguish several types of coping behavior: proactive coping, reflexive coping, strategic planning, preventive overcoming, search for instrumental support, search for emotional support [18]. Analysis of human behavioral reactions in a professional environment requires highlighting the features of the reflexive process in problematic interaction. And therefore, it is considered logical to comprehensively consider the problem of professional reflection in the process of the activities of teachers [20], psychologists [11], doctors (Hedy, 2015) and social workers [9]. At the same time, the importance of reflection in the formation of professional identity, in overcoming professional deformation, as an attribute of interactions with patients, clients, pupils and students is emphasized. In a broader aspect, coping behavior is seen as an effective means of overcoming organizational stress and burnout syndrome, and in specific situations, "reflexive coping includes assessing possible stressors, analyzing problems and available resources, generating an assumed action plan, predicting the likely outcome of activities and choosing methods. Its implementation" [19].

Thus, we can say that the study of coping strategies, in which a special role belongs to the process of reflection, is relevant in a wide range of types of human professional activity. In this case, reflection must be considered as a property of synthetic mental reality, which can act (and actually does) both as a mental process, and as a mental property, and as a mental state at the same time, but cannot be reduced to any of them [13]. And in the case of professional activity, reflection manifests itself as a process during which practitioners identify problems in the process of critical assessment, and then develop potential solutions [1]. The aim of the study was to develop a two-sided universal model for assessing and choosing a strategy of behavior in such situations on the basis of substantiating the features of the manifestation of the process of professional reflection in conditions of problem interaction. Awareness of these features and practical skills of effective cooperation can contribute to improving the professional skills of a specialist in the process of optimizing organizational activities and successful interaction with people of various typologies. These issues also acquire relevance due to the fact that conflict situations 
arise in the working environment, both in the horizontal and vertical plane, and during external interaction. The upward trend in conflict-generating tensions is often associated with modern transformations of society, competition and reforms in the labor market. Obviously, for many employees of organizations of various profiles, the professional environment has a conflict-generating nature, which is associated with a distant relationship between a manager and employees, a lack of a trusting environment, isolation of governing bodies, tough administration and a demonstrative emphasis on the hierarchy of the official position, its dominant status.

In the applied research of social psychologists, you can find different classifications of "problem" partners or collaborators. From a psychological point of view, all these types or types of "problematicity" are of interest and can be interpreted, since their assessment and characteristics depend on specific psychological factors. The degree and forms of "undesirable" strategies are subjective and have a certain meaning for each individual, as well as the sociopsychological context. And this is increasingly manifested in the process of communication, interactions that take place in a formal environment and are regulated by certain norms of behavior. The ability to identify and evaluate the specific behavior of employees, as well as the skills of working with such a contingent, characterize the professional skill and creativity of the subject of management.

E. Clayton (2010) notes that many psychological studies offer several ways to cope with such difficult people in everyday life as hostile employees, strict bosses, complainants, super conciliators, omniscient experts and pessimists. Based on the experience of many years of clinical work in the field of organizational psychology, the author believes that when interacting with such people, the main method is selfhelp, i.e. deliberately overcoming and consciously controlling personal weaknesses and working to overcome these weaknesses and improve oneself. The paper considers an approach according to which "self-help primarily focuses on changing your behavior, feelings, skills, cognition (thoughts) or unconscious processes. Selfhelp is a conscious part of you that changes other aspects of your inner self, your actions, and your situation (Clayton; Tucker, 2010). This approach requires a clearer interpretation, namely, the interpretation of personality traits and their behavioral reactions. It is more correct to interpret "self-help" as a conscious selfregulation, the direction of which directly comes from the process of reflection.

From our point of view, the six types identified by E. Clayton do not cover the entire spectrum of negative manifestations of problematic interaction, and the approach to recognizing "harmful" employees can be supplemented by visualization of the typologies themselves and their detailed description. Significant in the considered approach is that the detailed and fairly applied method of forming "selfhelp" has the goal of changing one's behavior based on professional reflection. Our 
approach also implies a reflexive attitude to the proposed typology of "undesirable" personality manifestations and self-esteem, as well as the search for ways to overcome them in interaction with others and to correct self-awareness.

Methods. Based on the study of the concepts and approaches of the aforementioned authors, a modified version of the projective method by $\mathrm{H}$. Avanesyan (2015) "The projection of the professional reflection". In the various typologies examined, common signs of behavioral reactions and characteristic features were identified, on the basis of which an expressive drawing was selected for each of them according to the genre of artistic hyperbole, in which the image had the effect of exaggeration and pointed characteristic features. This method has been combined with Lazarus's coping test and content analyses method.

The compilation of psychological criteria for assessing personality manifestations and behavioral strategies included the analysis of some other approaches and applied research. One of them is related to the classification of unmanageable employees [4]. Psychologists D. Waldroop and T. Butler provide an equally interesting classification of employee behavior [5]. They describe six types of career behavior that can cause problems for both coworkers and managers $L$. Glass identified the types of "poisonous" people and offers methods for interacting with these people, not allowing themselves to adopt them. The list of psychological characteristics includes 30 topologies [10].

After substantiating the theoretical and methodological base and choosing the psychological and pedagogical principles of sequence, visualization and reflection, preliminary research and main implementation stages of work were carried out with the last version of "The projection of the professional reflection". The preliminary stage of the study involved solving the following tasks: selection of typologies with different behavioral manifestations; translation from English and Russian versions of names; survey of respondents; selection of drawings for each type; a survey of respondents for drawings without inscriptions; matching and ranking selected type names; development of presentation version (PowerPoint program with phased highlighting). This stage included the following steps: 1) an untitled drawing; 2) text about the type of person or behavior; 3) the causal characteristics of the type of personality or behavior. More than 500 people (YSU students and teachers, students of advanced training courses for government and commercial organizations) took part in the method testing procedure. The technique went through all the stages of design - a pilot study, an expert survey, the selection of the best pictures, a pilot and a formative experiment.

Results. In the various typologies considered, common signs of behavioral reactions, coping strategies and characteristic features were identified, based on which an expressive pattern was selected for each of them. After a pilot study to describe "problem types" (more than 40), the most typical ones were selected from 
a variety of drawings, which were included in the presentation block of the training and received an Armenian "accent" (the types were renamed following the accepted Armenian vocabulary and terminology). "The projection of the professional reflection" method solving the following tasks: familiarization, characterization, assessment and self-assessment, with a further search for individual strategies. Neutralization of the negative consequences of "psychological games" of employees acting as "toxic", "problematic", "difficult", "uncontrollable", etc., will be successful only if the role stereotypes of employees are correctly identified and appropriate management strategies are applied. Thus, a specific environment of service communication with colleagues and managers was modeled, contributing to the development of professional reflection.Interpretation of the content, motives and main reasons for psychological manipulations can help to understand such features of students' behavior, make communication with them more constructive and effective. The ability to recognize different typologies at the same time can contribute to an adequate analysis of both one's behavior and it is easy to evaluate actions and their meaning in the behavior of others and themselves.

According to the results of the content analysis to identify the latent content of the survey texts, which was carried out after viewing the slides and familiarizing with the characteristics of the proposed types. So it was according to the content of open answers that the majority of participants projected on colleagues or managers: "they are." "We have a lot of similar ones", "chefs become like that" "found a specific colleague", "this is common" (47\%), and more rarely "sometimes necessary "," sometimes necessary ", "they force me " $(31 \%)$, and there were answers with twofold content (22\%). Based on the selection of the most common associations, the final version of the methodology was formed. An association experiment was conducted, during which the participants looked at the drawings and wrote at least 5 associations on a piece of paper. The results of the projective methodology were compared with two other test methods (the social self-control test and the Proactive coping behavior questionnaire). As a result of approbation and correction of the projective technique, the figures were edited. Conclusions. Consequently, we can conclude about the effectiveness of the experimental version of the course "Psychology of Problem Interaction", which influences the reflexive attitude to behavioral manifestations and contributes to the increase in the level of knowledge and the formation of practical skills in resolving problem situations. Based on a methodologically substantiated comprehensive study, the behavioral coping strategies of employees, conditioned by the organizational model and management style of the manager, were identified and characterized. Thus, focusing versus avoidance is more effective in promoting adaptation than not controlling behavior (Suls; Fletcher 1985). 
Based on the study of the individual psychological characteristics of the manager and the most adapted employee with a stable developed culture of the organization, a scheme of professional interaction was developed, which allows choosing the most effective coping strategy for both the employee and the manager.

\section{References}

1. Argyris C., Schon D. Theory in Practice Increasing Professional Effectiveness. 1st Edition, San Francisco: Jossey-Bass Publishers, 1974.

2. Carver C. S., Scheier M. F., \& Weintraub J. K. Assessing coping strategies: A theoretically based approach. Journal of Personality and Social Psychology, 56 2, pp. 267-283. 1989, https://doi.org/10.1037/00223514.56.2.267

3. Clayton E., Tucker L. Psychological Self-Help. Self-Help Foundation, 2010, https://www.psychologicalselfhelp.org/Chapter1/chap1_2.html.

4. Loehr A., Kaye J. Managing the Unmanageable: How to Motivate Even the Most Unruly Employee. Career Press, West Parkway. Incorporated, 2011, $256 \mathrm{p}$.

5. Waldroop J., Butler T. Managing Away Bad Habits. Harvard Business Review. Vol. 74, No. 5. Cambridge, MA, United States, 2000, pp. 79-90.

6. Аванесян Г.М. Метод визуализации в тренинговых занятиях по развитию навыка профессиональной рефлексии. Материалы международной конференции «Актуальные проблемы теоретической и прикладной психологии», Ереван: Эдит-принт, 2015, с. 303-308"

7. Бессер-Зигмунд К., Зигмунд Х. Самокоучинг: Культура личности менеджеров и руководителей. СПб.: Изд-во Вернера Регена, 2010.

8. Бурдье П. Структура, габитус, практика // Журнал социологии и социальной антропологии, Санкт-Петербург, Том I,. № 2. 1998 с. 60-70.

9. Воронцова М. В. Профилактика и преодоление профессиональной деформации специалистов социальной работы. Учебно-методическое пособие. Таганрог: Изд-ль А.Н. Ступин 2013, 272 с.

10. Гласс Л. Вредные люди вокруг нас. Как с ними бороться? СПб.: Питер, 2008.

11. Голянич В.М. Введение в профессию: психолог: учебник и практикум для академического бакалавриата. Москва: Издательство Юрайт, 2016, 365 c.

12. Занковский А.Н. Организационная психология. М.: 2-е изд. Флинта: МПСИ, 2002.

13. Карпов А.В. Рефлексивность как психическое свойство и методика ее диагностики, Психологический журнал. Т. 24. № 5. 2003, с. 45-57.

14. Леонтьев Д. А. Очерк психологии личности, М.: Смысл, 1993. 
15. Майерс Д. Социальная психология, СПб.: Питер, 2007, 794 с.

16. Моросанова В.И. Индивидуальные особенности осознанной саморегуляции произвольной активности человека. Вестник Московского университета. Сер. 14. Психология. - №1., с. 38-41, 2010.

17. Рассказова Е. И., Гордеева Т.О., Осин Е. Н. Копинг-стратегии В структуре деятельности и саморегуляции: психометрические характеристики и возможности применения методики СОРЕ. Психология. Журнал Высшей школы экономики, 2013.Т. 10, №1. с. 82118.

18. Старченкова Е.С. Концепция проактивного совладающего поведения. Сер. 12. Вып. 2. Ч. І., Питер. Вестн. С.-Петерб. Ун-та. 2009, с. 198-206.

19. Старченкова Е.С. Проактивное совладающее поведение. В кн. Водопьянова Н. Е. Психодиагностика стресса. СПб.: Питер, 2009, с. 275-276.

20. Эрнест Г.Г. Профессиональная рефлексия как механизм саморазвития будущего педагога. Концепт, 2015: http://e-koncept.ru/2015/15413.htm (15.07.2020).

\title{
ПСИХОЛОГИЧЕСКАЯ ОБУСЛОВЛЕННОСТЬ ПРОФЕССИОНАЛЬНОЙ РЕФЛЕКСИИ И ПОВЕДЕНЧЕСКИХ СТРАТЕГИЙ В СИТУАЦИЯХ ПРОБЛЕМНОГО ВЗАИМОДЕЙСТВИЯ
}

\author{
Аванесян Г.М., Карапетян Н. И., Мурадян М. Д. (Ереванский \\ государственный университет, Ереван, Армения)
}

В статье анализируется проблема межличностного взаимодействия в процессе совместной деятельности, которая была и остаётся одной из важных в социальной, организационной психологии, психологии управления и образования. На основе рассмотрения, имеющихся классификаций «нежелательных», “сложных», «вирусных» и т. п. партнёров совместной деятельности, выделенных в научно-прикладных исследованиях, выявлены характеристики и критерии оценки указанных типов и осознанных поведенческих стратегий. Цель исследования предполагала на основе обоснования особенностей проявления процесса профессиональной рефлексии в условиях проблемного взаимодействия разработать двухстороннюю универсальную модель коррекции элементов самосознания, оценки и выбора стратегии поведения в подобных ситуациях. Сопоставление психологических критериев оценки личностных проявлений и поведенческих стратегий в условиях преодоления проблемного взаимодействия, позволило разработать и апробировать тренинг, который способствует формированию навыка саморегуляции, оценки и 
выявления «проблемных» партнёров, с дальнейшим поиском индивидуальной стратегии поведения.

Ключевые слова: профессиональная рефлексия, поведение, проективная реакция, личность, взаимодействие, сотрудник, стратегия совладания, тренинг.

\section{UUULU9hSU4UL กt\$LteUhU3h tч 4URคU3hl

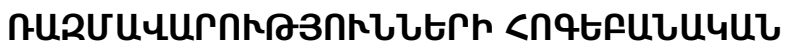

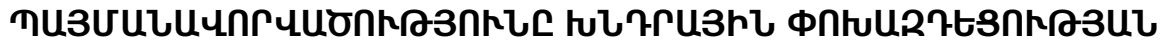

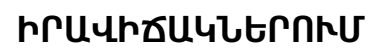

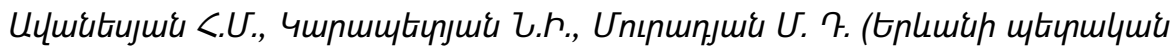

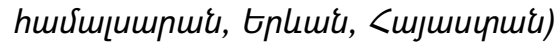

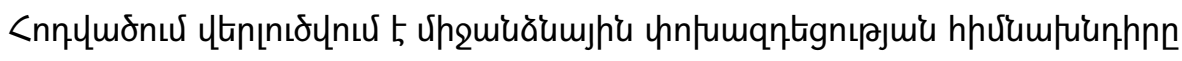

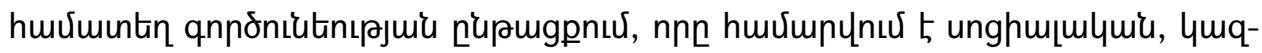

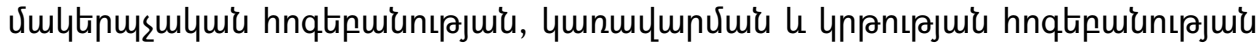

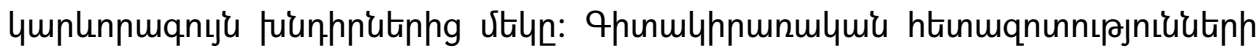

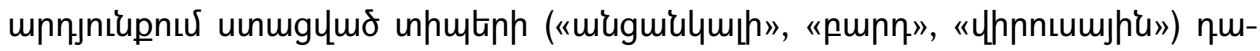

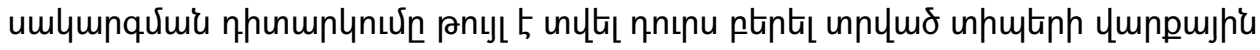

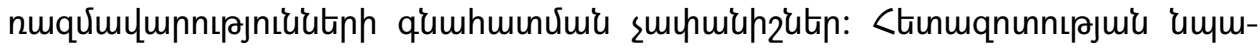

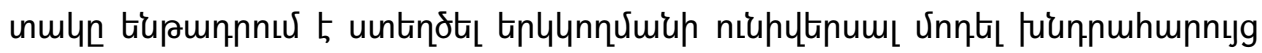

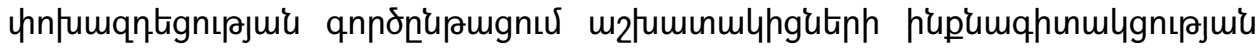

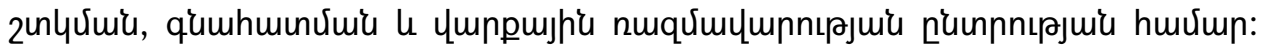

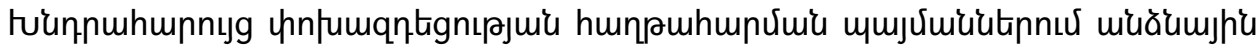

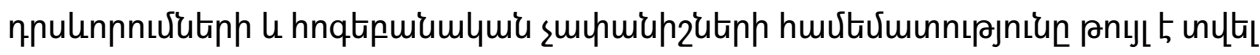

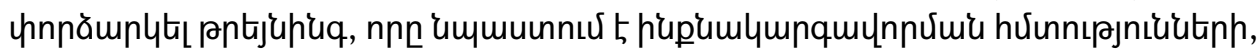

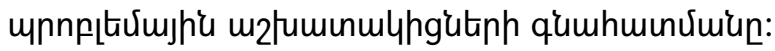

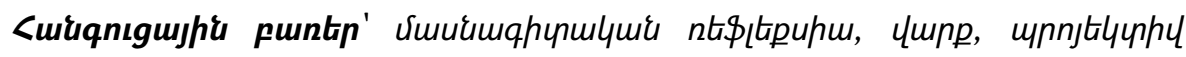

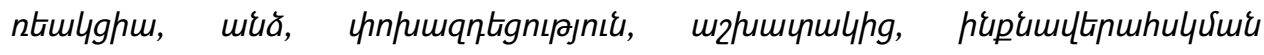

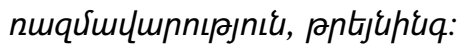

